\title{
Dynamics of Politics and Poetics of Home: A Study of Manju Kapur's Home
}

\author{
Ms. Adwitiya Gope ${ }^{+*}$ and Dr. Gyanabati Khuraijam
}

\section{Abstract}

The territory of the home is not only regarded in terms of physical space but also in terms of human affection and influence. The status of women within the social structure of their families and/or communities is paralleled as well as informed by their position in the physical structure of their houses and homes. An Indian woman is yet to seek an identity as a human being with equal status in the family in which she is born and in the family to which she is given in marriage. This research attempts to make a study of Manju Kapur's novel Home to reveal many issues deeply rooted within a family and explore the dynamics of relationships that prevail in an Indian home. Nisha, the protagonist in the novel, tries to subvert age-old traditional norms and values of her home, which is symbolic of Indian society in microcosm, that threatens to subvert her existence as an individual. Manju Kapur's women contest and defend their domestic territories because they are contesting not only for power, but for their self-esteem, identity and individuality. The home obviously is a gendered living space of an everyday life, and that young Indian women are not accepting traditional roles conferred by 'home' onto them passively; instead, they seem to be (re)traditionaliszing their strategies of housework and childcare responsibilities. Through this paper we wish to highlight that change in the traditional roles played by women in homes reproduces dynamics of politics of home thereby enhancing dynamics of poetics of home. The study of politics and poetics of home further analyses how the relationship between women and men as well as ideas about masculinity and femininity are shaped by the intersection of tradition and modernity. The study explores a dialogue between tradition and modernity with an aim to project yearning for autonomy and separate identity. Kapur poignantly shows the evolution of an Indian woman in the midst of the repressive patriarchal structure of an Indian home.

Keywords: Home; Space; Patriarchy; Tradition; Modernity, India

\footnotetext{
${ }^{\dagger}$ Assistant Professor, Department of Science \& Humanities, Tripura Institute of Technology, Tripura, India

${ }^{*}$ Corresponding Author, Email: adwitiya10@rediffmail.com

${ }^{¥}$ Assistant Professor, Department of Management, Humanities \& Social Sciences, NIT Agartala, PO - NIT Agartala, Jirania, Tripura West - 799046, Email: khgyan79@yahoo.com

(C) 2019 Gope \& Khuraijam. This is an Open Access article distributed under the terms of the Creative Commons Attribution License (http://creativecommons.org/licenses/by/2.0), which permits unrestricted use, distribution, and reproduction in any medium, provided the original work is properly cited.
} 


\section{Introduction}

The territory of the home is not only regarded in terms of physical space but also in terms of human affection and influence. Home marks the boundary between an inside and an outside space; a space both physical and social. Taking these arguments into context, this research is an attempt to critically analyse Manju Kapur's novel Home.

To accomplish this objective, this research begins with a brief theorisation of the notion of 'home'. In doing so, it demonstrates how the notion of home intersects with gender and patriarchal culture to produce domination and exploitation. Following this, it analyses Manju Kapur's Home. In the next section, though, we analyse the notion of 'home'.

\section{Home}

The word 'home' has got many connotations in the intellectual spectrum of postcolonial studies (Burton, 1998; Mee, 1998; Wiemann, 2008; Bhattacharya \& Singh, 2018; Das et al., 2015; 2016; Vauquline, 2015). While the 'home' is a site of peace, comfort, camaraderie for many; it can also emerge as a site of violence (Bhattacharya \& Singh, 2018; Das et al., 2015; Vauquline, 2015). As Antoinette Burton (1998:122) commented that:

Of all the ideological subjects to be contested by feminism, post-modernism and post-colonial theory, 'home' has come under the most rigorous scrutiny and, paradoxically, has exhibited the most resilience in the past few decades. (Burton, 1998:122).

The paradox lies in the meaning of the term 'home', which reverts back to the territory of everyday domicile as well as to the interpretations concerning immigrant perspectives. In his article, entitled The Politics of Home: Postcolonial Relocations and TwentiethCentury Fiction by Rosemary Marangoly George Jon Mee (1998: 542) expressed that:

The Politics of Home begins, however, with a discussion of the fate of the concept of home in recent interdisciplinary scholarship,...that there is a pressing need to separate nationalism at the level of elite scholarship, political rhetoric, jurisprudence and state- building from the imagining of a place as one's home that functions on the everyday level of ordinary people as they write and live ordinary lives (Mee, 998: 542).

Jon Mee (1998:543) further commented that:

George shows domestic sphere 'as a kind of spiritual entrapment, but without acknowledging any route for liberation' (Mee, 1998: 543).

Dirk Wiemann (2008: 213) described home as an organised system having its extensive structure where the domestic is run:

Home, now conceived of as a place in the world, partakes of a continuous and extensive structure within which the domestic is contained, retaining its very own features as a self-organising system (Wiemann,2008: 213).

Seemingly, in their empirical research on abandoned widows of Varanasi, who lives in ashrams (hermitages) Bhattacharyya and Singh (2018) analysed the notion of ashram as a living entity and home. The ashrams have become 'home' for the widows (the authors have addressed them as 'matas'). In doing so, Bhattacharya and Singh (2018: 767) argued:

Indeed, these ashrams are sites wherein these Matas have been building 'a sense of belonging'.

Bhattacharya and Singh (2018) further quoted Blunt and Dowling (2006) to provide a theoretical baseline to the understanding of the concept of home:

Blunt and Dowling (2006: 254) argued that "home is a process of creating and understanding forms of dwelling and belonging. Home is lived as well as 
imagined. What home means and how it materially manifests are continually created and re-created through the everyday home-making practices, which are themselves to spatial imaginaries of home" (as cited in Bhattacharya and Singh, 2018: 767).

It is arguable that the mechanics of domestic life is entrapped within the space of domicile of the individual's condition- the psycho -sociocultural orientation of the particular individual. The main crux of the research is to explicitly present how this orientation of individuals, cognitive of different levels, that is, psychological, sociological or cultural is manifested in individual woman as a 'self'. It has to be mentioned here that this study does not consider whether this manifestation is appropriate or not but rather "how" (politics of home) the psycho-socio -cultural conditioning gets manifested in individual woman self. However, an analysis of 'politics of home' of Manju Kapur's Home immediately implies the analysis of 'poetics of home', that is, development of healthy mechanics of domestic life.

The study of politics and poetics of home further analyses how the relationship between women and men as well as ideas about masculinity and femininity are shaped by the intersection of tradition and modernity. However, exploration of the theoretical background of tradition, modernity and patriarchy is carried out in the next section with an objective to fix the role played by them in the novel Home.

\section{Tradition and Modernity}

Postcolonial India witnessed the changing status and role of Indian women. Indian women became an emblem of the paradoxical mix of traditional practices and modernity (Bhattacharyya, 2018). Though tradition and modernity appear to be in constant opposition to each other, both the concepts are never limited by space and time. Tradition is referred to as a variable rather than a fixed or static concept (Hobsbawm, 1983). Hobsbawm defined tradition as:
It does not preclude innovation and change up to a point, though evidently the requirement that it must appear compatible or even identical with -precedent imposes substantial limitations on it. What it does is to give any desired change (or as expressed in history (Hobsbawm, 1983: 2).

Continuity of social practices and norms is ensured to be handed down from one generation to the other in a society. In a patriarchal society, such traditional practices are embodied and often identified with women selves; women become the prime bearer of traditional beliefs and custom. Certain social practices that are considered as traditional are actually 'constructed' or 'recently invented' (Hobsbawm, 1983: 1). Yuval-Davis (1992), further pointed at the politicisation of the term 'tradition' when she remarked that tradition reinforced the complexity of conservative gender relations. In Indian societies, like other societies of the world, religious and traditional practices are primarily sustained through the institution of family. The family headed by a patriarch, functions as the machinery through which 'tradition' should be moved from one generation to the other. The male members and aged female members are often identified as 'patriarch' in a system of social structures who are primary bearers of traditional practices. In the Indian context, patriarchy is used to describe a family relationship dominated by a male 'patriarch' in a system of social structures used to oppress and exploit women (Bhasin, 1993: 3). Patriarchy thus works as an invisible authority of social practices and norms through which they (patriarchs) maintain their dominance over women folk in general.

However, with the advent of modernity, women started developing resilience towards patriarchal forces. In response to the feminisation of labour force, Bradley (1999: 212) commented that "women are no longer readily prepared to accept their subordination as something natural or to acquiesce with male views of their inferiority as workers." 
This research argues that similar such transformation is also occurring in India. Chakrabarty (2002) discussed the role of the past in driving the modernity of colonial countries, especially India. Most Indians grow up with some or some aspects of practices of tradition as a process of socialisation. Coming to the discussion of Manju Kapur's Home, it is observed that while some traditions are unaltered, others are altered (due to introduction of modernity). Manju Kapur's Home exposes that tradition and modernity are not always put as extreme poles rather they coexist in Indian society.

Nonetheless, it is arguable that tradition is a highly contested and a variable concept (Hobsbawm 1983) where traditions and modernity coexist in Indian society, and that young Indian women are not accepting traditions passively, instead they seem to be (re)traditionalizing their strategies of housework and childcare responsibilities (Bhattacharyya, 2009; 2019). We see that Nisha, the protagonist of Manju Kapur's Home, aspire to make the most of her educational capital while at the same time recognising the embodiment of socio-cultural values in established domestic and family roles, norms and obligations. This points to a reinvented tradition [that is (re)tradition] at the intersections of class and gender. Nisha demonstrates shifts in certain gendered practices of tradition in her everyday life in order to build her modern identities of having "allmine"(Kapur,2006:337); a career, a marriage, and motherhood while at the same time retain other practices unaltered (see, Bhattacharyya, 2009; 2019).

The discourse of tradition and modernity has been the dominant idiom that has sought to reproduce the dynamics of politics of home. Women are often projected as traditional cultural emblems of Indian society in general and Indian homes in particular. Any changes in their stereotypical roles as mothers, daughters, sisters are hastily condemned as threats to culture and tradition. Such responses have been witnessed in many occasions in the novel; be it upbringing of first-generation daughters like Sona and Rupa or upbringing of next-generation daughter
Nisha, the only objective of the mothers behind upbringing of the mentioned daughters rests on to make them fit to support traditional domestic roles of women once daughters get married. Such responses can be read as a response typical of patriarchal societies. In similar context, Maitrayee Chaudhuri (2012) commented that:

Changes to "tradition" had to be condemned on two grounds-one, that they ran counter to "natural" patriarchal norms and two, that they are alien and western (Chaudhuri,2012: 280).

In the following sections, we analyse Manju Kapur's novel Home.

\section{Manju Kapur's Home}

As stated above, Manju Kapur's novel Home delineates that change in the traditional roles played by women in homes reproduces dynamics of politics of home, thereby enhancing dynamics of poetics of home.

Manju Kapur is a contemporary Indian writer who in her fictional works dealt with Indian family systems and the roles played by the inhabitants of Indian homes who contribute significantly in the churning of dynamics of relationships in the homes that they lived in. Published in 2006, Manju Kapur's Home is her third novel, which is an engrossing story of family life, across three generations of the Banwari Lal family. Home is a saga of Indian joint (extended) family system where more than two generations live together (Bhattacharyya, 2009). The author gave a brief synopsis of the family dynamics of the Banwari Lal family at the very outset of the novel:

The Banwari Lal family belonged to a class whose skills had been honed over generations to ensure prosperity in the market-place. Their marriages augmented, their habits [are] conserved. From an early age, children were trained to maintain the foundation on which these homes rested. The education they received, the values they imbibed, the alliances they made had everything to do with protecting the steady stream of gold and silver that burnished their lives. 
Those who fell against the grain found in their homes knives that wounded and once the damage had been done, gestures that reconciled (Kapur, 2006: 1).

This prologue to the novel clearly marks the set pattern of the joint family system of the Banwari Lal family. Everyone living in the family had to contribute to maintaining the greater interest of the joint family; individual interest should be subservient to the mass interest of the family. Maneeta Kahlon (2011) seemingly in her article entitled "Family Structure in Manju Kapur's Difficult Daughters and Home." talked about Anupama Chowdhury who commented:

Home reveals a disturbing home truth that joint families can both destroy and preserve our maturity, individuality and mental progress (Kahlon, 2011: 4).

The status of women within the social structure of their families and/or communities is paralleled as well as informed by their position in the physical structure of their houses and homes. An Indian woman is yet to seek an identity as a human being with equal status in the family in which she is born and in the family to which she is given in marriage. In this context, Lisa Lau (2006) commented:

Much of contemporary South Asian women's literature reflects the importance of home to women; their writings frequently include detailed descriptions of the interior spaces of home, the negotiation of roles and hierarchies, and the emotional lives played out against a background of the bedroom and the kitchen (Lau,2006: 1098).

Lisa Lau (2006) quoted Marangoly George when she said:

Although home is traditionally associated with being a haven and a sanctuary, and 'the word home immediately connotes the private sphere of patriarchal hierarchy, gendered self-identity, shelter, comfort, nurture, and protection' (George 1995: 1), home can be the central site of oppression for some women (Lau, 2006: 1111).

In a similar argument, Vauquline (2015) opined that:

The very definition and understanding of a home as a place where people cohabit in peace and harmony is increasingly becoming questionable in today's context...It has now complex and multivalent meanings. Along [with] as a site of privacy and freedom of expression, it has also become a site of oppression...for many women home is a battleground, not a safe haven (Vauquline, 2015: 56).

Home is arguably regarded as a place where a family lives together, and everyone feels secure oneself in the four walls of the home. However, Manju Kapur's novel Home presents home as a place where the life of a woman is confined only to serve and to obey nuanced cultural values, norms and customs and rituals; and this tradition should be passed on to the next generations also like the values of the family. There is no place for women's desires, no freedom for their aspirations and potentialities. Gender segregation in the home is rigorously enforced by the inhabitants' knowledge of the customs of the home. Kapur's novel Home is a splendid illustration of how space of domestic territory is gendered. Specific spaces of the home are restricted by gender, or restricted in terms of times of access, depending on gender. The house of Banwari Lal provides an example of how the physical structure of the home and its rules limit and shape the identities and roles of its inhabitants. These observations bear resonance with the arguments as put forward by Burton (1998); Mee (1998) and Wiemann (2008). The roles women play within their families and homes often go a long way in the shaping of their self-perception, self- esteem, identity and individuality. It is interesting to observe that Manju Kapur is fully aware of such nuances of domestic space and identity of women and therefore Kapur seeks to effect changes in the later by altering the former. Extension of Nisha's domestic space to the basement of the home, 
where she had opened up outlet of her creative works, namely, "Nisha's Creation", is an example of such effort made by the writer to affect changes in the domestic space and providing more space to shape the identity and self esteem of women thereby reproducing dynamics of politics of home.

It is observed that the spaces and politics of home feed into the notions of identity and self worth on the part of women. The novel Home exposes the joint family system of an Indian home which, with its particular gendered spaces and hierarchies of power dictate and limit the interactions of its members and pattern the relationships formed within them. The next section is an attempt to make a nuanced discussion of Home.

\section{Analysis}

The home unfolds domestic territories of three homes - the Banwari Lal's, Rupa's and Nisha's homes (both parental and in-laws). Majority of the novel gives a brisk account of Banwari Lal's home. The Banwari Lal's home comprised of three generations residing in one house: Lala Banwari Lal and his wife, his children Yashpal, Pyare Lal and their wives Sona and Sushila, and his grandchildren Ajay, Vijay and Nisha. His daughter Sunita was married when she turned eighteen.

\section{Banwari Lal's Home}

Lala Banwari Lal was a patriarch who firmly believed in living in a joint family. He was the head of the family who run a saree shop in Karol Bagh. His two sons - Yashpal, the eldest son and Pyare Lal, the younger one were brought up in such a manner that they should always contribute to maintaining the interest and integrity of the family:

The two sons had been brought up to consider their interests synonymous with those of the family. The patriarch was keenly aware of any disagreement between them. Neither must feel exploited, but the eldest had to have the final say. This was not a democracy, in which freewheeling individualism could be allowed to wreck what was being so carefully built (Kapur, $2006: 7$ ).

Yashpal's declaration of his determination to marry a girl of his own choice appeared detrimental to their family values. According to Banwari Lal, marriages should be made with great care so that the prosperity of the home continued in terms of wealth and fame:

In order to remain financially secure, and ensure the family harmony that underpinned that security, marriages were arranged with great care. The bride had to bring a dowry, come from the same background, and understand the value of togetherness. Falling in love was detrimental to these interests (Kapur, 2006 : 4).

Given the backdrop of such political construction of the domestic territory of Banwari Lal's, the marriage of Yashpal and Sona was agreed upon as the name of the bride connoted wealth: "Gold. Sona. It was the girl's name, and ... the word took on the hue of a good omen" (Kapur, 2006: 8). Sona was accepted initially by her inlaws not because of her personality traits or because of her individual attributes but because of her name which was parallel to wealth. Yashpal's mother's resentment for Sona at their very first meeting clearly indicated the family equation of the Banwari Lal's:

The thought of her favourite son entrapped by a clever, manipulative, dowryless creature made it barely for her to look pleasant during the visit her husband forced her to make (Kapur, 2006: 8).

Sona had to face ill-treatment in her new home as she was a "dowryless creature":

Every gesture suggested the daughter-inlaw had no right to exist, and if she had to live, why was she doing it in their house? (Kapur, 2006: 12).

Dowry is a practice which is largely prevalent in South Asian countries like India and Bangladesh, where the groom or the groom's parents place 
some form of demand (usually money, property or luxury gifts like the car, bike) on the bride's family. It is indeed a form of violence against women, especially domestic violence inflicted on the bride if the bride's parents are unable to fulfil the demand of the groom's side. Here, Sona, the daughter- in - law of Banwari Lal has been a victim of dowry. This finding validates the research findings of Das et al. (2015) in their research on domestic violence against women in Sylhet, Bangladesh where the authors argue that: "[d]owry is a mandatory demand for marriage and no woman has escaped from the vicious cycle of dowry" (Das et al., 2015: 116).

The physical space available for its inhabitants to have access to continuing to be important not only as the primary arena of social life for Indian women but also as a space loaded with implications of their worth and their social positions. This is why the battles for increased social status naturally take place in terms of domestic territory. Manju Kapur's women are no exception to this. Manju Kapur's women contest and defend their domestic territories because they are contesting not only for power but also for their self-esteem, identity and individuality. They want to have a little living space where they could exist with some self- worth and degree of security. The story of Sona's married life and Nisha's life before and after her marriage does conform to this struggle of womenfolk in general. Sona's first encounter with her new home after her marriage appeared to be shocking to her as certain spaces of the house was not accessible to her:

Why, this house is smaller than mine, thought the young bride, as she surveyed the small paved area between front door and gate, the angan at the back, with its toilet and kitchen on opposite ends, and the four rooms in between (Kapur, 2006: 10).

Having married to an affluent business family, Sona was astonished to find a congested living place in her in-law's house, where the "upstairs" was rented to tenants. On her demand of moving to upstairs, her husband, Yashpal consoled her saying: "May be, when the children come'... 'we can move upstairs...'" (Kapur, 2006: 10). However when Pyare Lal's marriage was settled with "the daughter of one of the wholesale cloth dealers in Chandni Chowk" (Kapur, 2006: 12), the tenants upstairs were asked to move because "[a] bride of this quality" (because she would bring many luxury items as dowry along with her) could not be asked to live in a congested place. Meanwhile, Sona having a barren womb even after two years of her marriage only seemed to pine for more space in the house: she longed to live upstairs, which she was always denied. Instead, she was all the time ridiculed by her mother-in-law for being barren. Nevertheless, Sona was successful in achieving her position, her new home only after she became pregnant after ten years of her marriage.

Just because Sona did not belong to an affluent family and therefore could not bring much of dowry as expected by Banwari Lal's home, Sona was very careful to keep the favour of the family towards her:

Perhaps her relative poverty would ensure the necessary amount of gratitude needed to be an ideal daughter-in-law (Kapur, 2006: 9).

Sona moved with confidence in her new home on a firm footing on which to begin staking territory. Sona with her pregnancy and thereby her potential to present the family with a new member- a progeny, an heir, could extend the reach of her domestic territory and comfort zones, negotiate for the increase of her sphere of influence, and tip the balance of politics of power at home in her favour. Sona eventually claimed the entire territory of the home.

\section{Rupa's Home}

The novel began with the story of two sisters: Sona (the eldest daughter- in- law of Banwari Lal) and Rupa. Sona was the eldest and good looking and Rupa was the youngest and merely plain looking. Unlike Sona, Rupa continued her study and completed BA, "after which her father arranged her marriage to the son of a retired colleague, based in Karol Bagh" (Kapur, 2006: 16). Rupa's husband, Prem Nath was "a minor 
employee in the Defence Ministry" (Kapur, 2006: 16). Rupa's family comprised of her husband and her father-in-law. Rupa found the domestic territory of her home as very cosy and comfortable. The ambience of her home was full of mutual understanding, love and fellowfeeling. Though Rupa failed to conceive, she did not become a factor of social castration for being barren by her family members. Rather, Rupa found her family very supportive who all the time supported her to explore her individuality and self-esteem. Rupa started her own business, "a little pickle business":

Her husband encouraged her, her fatherin-law helped her paste on the labels with a trembling hand ... Rupa worked hard at her recipes, experimenting with new ones and expanding her repertoire (Kapur, 2006 : 17).

Contrary to Sona's home, the description of Rupa's home made the readers feel that the domestic space of Rupa's home was full of love and congenial relationship and never a politicised space like that of Sona's:

Rupa was childless but free from torment. She accepted her fate, she didn't spend every Tuesday fasting, she had no one to envy, no one to rub salt in her wounds, no one to keep those wounds bleeding by persisting hurting comments (Kapur, 2006 : 17).

The only tension of Rupa's life was a wicked tenant who lived upstairs in their house. He refused to pay his rent on time. They had already spent much money on the case to evict him.

\section{Nisha's Home}

Nisha was the first daughter among the grandchildren in the Banwari Lal family. The family overjoyed her birth as she was born to her parents after ten years of their marriage. Her birth released her mother from being abused time and again as barren. However, her birth as a daughter and not a son could not make everyone contented. In order to console in-laws of Sona, her sister, Rupa remarked:
'And now the womb has opened', continued Rupa, 'a baby brother will come' (Kapur, 2006: 37).

Gender discrimination is a pan-cultural phenomenon across the globe. In addition to gender inequalities - entrenched in patriarchal values, there remains a high persistence of son preference over daughters. This phenomenon is prevalent across class in South Asian countries (Bhattacharyya, 2017; Das et al., 2015, 2016).

Disparity made between a daughter and a son, between a male and a female is never a natural phenomenon, but it is the socio-politicalpsychological conditioning of a home, of a family that penetrates through individuals making them gendered human beings rather than distinct individuals. To take the words of Simone de Beauvoir (1983):

One is not born, but rather becomes woman. No biological, psychological or economic fate determines the figure that the female presents in a society, it is civilization as a whole that produces this creature which is described as feminine (Beauvoir, 1983: 16).

Again, Beauvoir commented:

The situation of woman is that she - a free and autonomous being like all creatures - nevertheless finds herself living in a world where men compel her to assume the status of the other (Beauvoir, 1983: 167).

At the naming ceremony of the newborn daughter baby, the gifts of gold that she received are saved as a contribution to her dowry"[w]ith this gold, Nisha's dowry was begun" (Kapur, 2006: 41).

Sona's delivery of her next progeny, a son was enjoyed and welcomed more than the first, the daughter. Sona's mother-in-law declared, "Now I can die in peace" (Kapur, 2006: 41). This is because, as mentioned above, a boy child is seen as 'Kul-Ka-Deepak'. A son is considered to be the bearer of 'family name'. On Rupa's protest against such discrepancies, the grandmother firmly retorted: 
Both sons should be able to hold their head high, not only one...Now the older one has a complete family (Kapur, 2006: 49).

Manju Kapur in her novel portrays the growth of a daughter from her infancy to her full-fledged woman. Kapur gives nuanced details of the growing years of Nisha and she sharply delineates the politics and poetics of a home that condition a woman. Nisha is conditioned by her family members from her very childhood that a woman is inferior to that of a man; the outside world should be accessible to a man and not to a woman. In the said context, Baby Ritu Phukan (2015) commented that:

According to radical feminists, the male supremacist ideology is perpetuated in its severest form within the domain of the family. The disparity between man and woman is a result of the complex operation of economic, social, political and other factors. Added to this are institutions like caste, gendered roles, joint-family, and religious values which serve to consolidate a woman's subservient and subjugated position. It is within this family structure that girlchildren experience their first feelings of being in the periphery and by virtue of being born a girl, is drilled the significance and importance of the institution of marriage (Phukan, 2015: 61).

Kapur conforms to this fact that the "family structure" conditions a girl from her very childhood to behave in a particular way. Due to gender segregation, the family never let Nisha go outside and play with her brothers. She spent a congested childhood where she was not allowed to play or go out on her own choice. She was provided with beautiful dresses and everything else yet, "unfortunately her outfits did not match her inclinations" (Kapur, 2006: 53). She declared, "I want to play in the park" (Kapur, 2006: 53). The home became gendered living space of day-to-day life. Kapur commented that:

From traditional Indian society, a woman under patriarchal discrimination is targeted to live and survive social ostracism. They are dealing with the unending struggle to enact an equal position to men in society. Manju Kapur's heroine, Nisha is forced towards domesticity and so-called family rituals under patriarchal notions. She is caught in the dichotomy between her personal wants and institutional liabilities. However, Nisha defies the oppressive mechanism of a closed society and asserts her individuality (Kapur, 2006: 20).

In her own home, Nisha, in her infancy stage, became a prey to the carnal desires of Vicky, the orphaned son of the daughter of the family, Sunita. Vicky tried to seduce her. It affected her psychologically and mentally, as even though as a child, she did not eat and sleep well. Though she was severely traumatised, she did not reveal her angst to anyone in her family. She thought that nobody in the family would believe her. Though Nisha was spending sleepless nights, her mother hardly bothered to know the reasons for her daughter's mental state. Instead "Raju's sleep was guarded fiercely by his mother" (Kapur, 2006: 65); such was the condition of her own home. However, Nisha was rescued from such a situation only by her aunt Rupa who took Nisha to her home. Nisha found the space and the environment of her aunt's home so congenial that she felt delighted living in her second home, that is, her aunt Rupa's home.

Nisha now found herself in an atmosphere very different from the one she lived in. As the only child, she was the centre of interest, concern and attention (Kapur, 2006: 68).

Rupa and her husband understood that Vicky was responsible for Nisha's miserable condition. They tried to tell her stories from Ramayana, gave her all care and love that she needed. It was in Rupa's home that "Nisha's greater education began" (Kapur, 2006: 70). She was admitted in class one in the best suitable school for her and for the next ten years her routine was designed as such that she stayed in her aunt's house all week and only in the weekends she came back 
to Banwari Lal's home and during her stay her father made it sure that Vicky was never close to her.

During the growing years of Nisha, she had shifted over homes, one of Rupa's and the other was her parental one. Manju Kapur had subtly portrayed the confused state of mind of growing up Nisha. The family traditions and the values of both the families were juxtaposed before Nisha. Nisha could see through the interplay of politics and poetics of both the homes, and she could design her own way of life. Nisha bloomed into a "new woman" who was a blend of tradition and modernity. Nisha rebelled against traditional beliefs and values of the home in which she was born. Nisha attempted to raise dialogue between tradition and modernity to project her yearning for autonomy and separate identity. She refused to reconcile with the patriarchal and male-dominated family structure and tried to make her own individual identity.

As stated above, Banwari Lal's home was traditional and patriarchal. Banwari Lal believed that education was not very important for a girl. A girl was supposed to find satisfaction in the performance of her duties in the varied roles of mother, daughter, sister, daughter-in-law etc. The home was considered as "Karma-Bhoomi" and women were not supposed to aspire for life beyond their domestic territory. Marriage should be the ultimate goal of a girl's life. As Simon de Beauvoir in The Second Sex (1983) put it:

The destiny that society traditionally offers women is marriage. Even today, most women are, were, or plan to be married, or they suffer from not being so. Marriage is the reference by which the single woman is defined, whether she is frustrated by, disgusted at, or even indifferent to this institution (Beauvoir, 1983: 451).

However, Nisha had been highly influenced by the ways of the home of Rupa's. Rupa's home gave primary importance to a girl's education. Nisha's stay with them had conditioned her mind according to the updated ways of thinking of her uncle and aunt. Nisha saw her mentor in her aunt who ran her own pickle business. Seeds of aspiration were planted in Nisha of becoming an independent individual like her Masi.

Sona did not understand her daughter Nisha very much like that of Kasturi in Difficult Daughters, the first novel of Manju Kapur published in the year 1998, where Kasturi, the mother of the protagonist Virmati stood opposed to her daughter's happiness and wishes. Both Kasturi and Sona were the forces of patriarchy within their homes. They were unable to understand their daughter's feelings and instead expected them to follow the traditional role of women in a family. Nisha was forced by her mother to perform the ritual of karva chauth, where a woman kept fast from dawn until moonrise praying for long life and welfare of her future husband (see, Bhattacharyya, 2019 for the definition). This activity of Sona was strongly opposed by Rupa as she said:

There was an age for everything, and when the child should be thinking of studies, she was forcing her to think of husbands (Kapur, 2006: 96).

In Rupa's home, Karva Chauth was never observed as she explained the reason for this to her niece, Nisha:

Your mother has to follow the traditions of her family. Besides, your uncle does not believe in fasting. If I don't eat, he won't eat either (Kapur, 2006: 96).

After the death of Banwari Lal, Nisha returned to her own home after eleven years of her stay in a very comfortable environment. On her return, Nisha found herself lost and misfit in her own home:

After eleven years Nisha returned home to assume her place as a daughter of the house, to learn the difference between weekend visits and full-time stay. Now there was less interest in her school, no pampering, and long hours expected in the kitchen (Kapur, 2006: 125).

Nisha continued to miss her uncle, her aunt's food, the quietness of their house. On the contrary, in her own home, "[h]er hands, altered 
from spotless white to nicked and burnt, reflected the change in her situation. Worst of all, no one imagined there was any lack in her life that needed to be filled" (Kapur, 2006: 129).

The traditional mother, Sona wanted her daughter to be like her. For her, doing kitchen work was more important than studies. The main concern of Sona was Nisha's marriage. As Nisha's horoscope revealed her to be a Mangli, it made her mother more anxious about her marriage. Throughout the marriage ceremony of Nisha's sibling, Ajay, Sona wanted Nisha to look beautiful so that any boy or his family might choose her. When Nisha returned home after living for a long time with her aunt, Sona discovered with horror that at the age of sixteen, Nisha did not know how to cook. "What can Rupa have been thinking of? I assumed she was teaching you everything she knew,' Sona grumbled. You take half an hour to peel ten potatoes. How will you manage in your future home?"(Kapur, 2006: 126). Nisha always protested in return, "Masi said there is always time to learn cooking, but only one time to study" (Kapur, 2006: 126). The girl always tried to defend herself and her aunt. This clash between Nisha and Sona was a clash between tradition and modernity. The mother wanted her daughter to be rooted in the tradition that would make her life worth living and she wanted her daughter to follow the tradition:

This is the life of a woman: to look after her home, her husband, her children, and give them food she has cooked with her own hands (Kapur, 2006:127).

Sona now initiated Nisha with the norms that would make her a worthy wife as Sona was ingrained very early in life that marriage was the ultimate destiny of a woman. Moreover, Sona did not want her daughter to be 'social wastes', as put by Beauvoir (1983):

For girls, marriage is the only way to be integrated into the group, and if they are 'rejected', they are social wastes" (Beauvoir, 1983:453).

Spaces and politics of home contribute to the formation of the identity of Indian women. The social environment of the parental home of Nisha is exceptionally antagonistic towards her blooming into a distinguished individual. The mechanics of the home of Nisha always want Nisha to 'fit in' the stereotypical roles destined for women. Contrary to Nisha's own parental home, her aunt Rupa's home is placed where Nisha gets the opportunity to breathe her life to the fullest. She does well in her exams while she stays in her aunt's house. As stated above, the death of the patriarch of the home, Banwari Lal, dragged Nisha back to square one. Her mother's interaction with her daughter every minute showed that a girl always needed to 'fit in' the set pattern of the gendered space of the home. She could have no other existence but had only to play either of the roles as a daughter/ daughter-in- law/ wife, sister/sister- in-law, mother/ mother-in-law.

However, on Rupa's insistence, Nisha was admitted to Durga Bai College to do her BA Hons. in English Literature. In the first year of her college, when she fell in love with Suresh. However, she became unable to take into confidence anyone from her own home to settle down their affair. Her aunt Rupa and uncle Premnath helped her to find a way out of her relationship, and the three met Suresh in a restaurant, though the relationship met its doom after this meeting. Hereafter, Nisha's aspirations of being economically independent germinated strongly within her. She wanted to do a fashion designing course. She faced strong opposition from her mother when she revealed her aspiration of working outside the home and earning. As already discussed above, she always faced oppression due to gender differentiation within the institution of the family in her own home. She was not allowed to work outside like her brothers. She requested her father:

If only you could take me with you, Papaji,' she pleaded in a rush. 'I have seen girls working in shops. Why should it be only Ajay, Vijay and Raju? There must be something I too can do (Kapur, 2006: 268).

Manju Kapur portrays the real-life struggle that an Indian woman undertakes while choosing her 
profession. Nisha was not allowed to work with her brothers in the shop because working in the shop was not considered to be a right profession for women; instead, her father arranged for her a job in a playschool. However, Nisha soon got fed up with children at the school and left the job. The novel explores a dialogue between tradition and modernity. Here, one can see that the modern type mirror's shop replaces the 'old fashioned' shop of Banwari Lal, and the 'home' is fragmented into flats. This change in the physical set up of the Banwari Lal's shop and home is evidence of the fact that the age-old tradition has to be modified to meet the demand of the time. Nisha also accepts modernity as she defies the traditional conventions of her home and with the help of her father, she starts her own business, a boutique, named 'Nisha's Creations' in the basement of her home. For the first time in her life. she felt proud as "[h]er father trusted her as he would have trusted a son" (Kapur, 2006: 291). She took money from her father to start the business, but she vowed to return every single penny to her father. She hired a tailor on monthly payments and collected material for suits from her father's shop. Her friends and customers started liking her suits and outfits. She started receiving big orders and became a successful and known 'businesswoman' of the Karol Bagh market. She became alert about her status as a reputed businesswoman. Kapur poignantly shows the evolution of an Indian woman in the midst of the repressive patriarchal structure of an Indian home.

Manju Kapur's Home summarised the idea of women's liberation and the protagonist Nisha emerged as a new woman in the novel. Nisha had a truthful understanding of 'personal worth', 'the pure mind' and 'the feelings of the heart', but such ideas were against the traditional patriarchal system. As an enlightened new woman, Nisha was at the crossroads of modernity and tradition. At this stage of life, when Nisha was able to create a distinct identity for herself as a successful businesswoman, her marriage was settled with a 34 years old mangli widower, Arvind of Daryaganj. With her marriage, Nisha shifted to her new home at
Daryaganj. Nisha struggled hard in her new home to manage both the worlds: her new home and Nisha's creations. Kapur vividly described her longing to get back to her work; she suffered badly when she became unable to attend to her business. After a month of her marriage, Nisha became pregnant, and her struggle to get back to her business became all the more difficult for her as her in-laws, as well as her relatives from parental side, suggested her not to continue with her work as her work might stress her and affect the health of the mother and the expected child. Gradually her sister-in-law, Pooja, took over her business, but Nisha stipulated that Pooja did not use the name "Nisha's Creations".

Ten months after Nisha's marriage, she gave birth to twins - a girl and a boy. Nisha contemplated high satisfaction as she enjoyed motherhood. She thought that "[h]er duty was over - God had been kind, however hard it was to believe" (Kapur, 2006: 336). But Nisha's life became more entangled by the traditions and conventions of her new home at Daryaganj.

Manju Kapur's novels present the changing image of women, moving away from traditional portrayals of enduring women, self-sacrificing women towards self-assured, assertive and ambitious women, making society aware of their demands and in this way providing a medium of self-expression. R. Jagatheeswari (2017) has opined that:

Manju Kapur's basic approach to a woman's life in her novels is to liberate them from the oppressive measures of the patriarchal symbolic order. In the process, the protagonists in her novels have sustained a lot of physical, emotional and psychological sufferings. These women have however achieved their long-sought freedom to a certain extent... The women's question today is, therefore, no longer an issue confined to the position of women within the family or their rights to equality with men in different aspects of social life, it is part of the total, far broader question regarding the direction of change that our society is taking - economic, social, political, and 
the intellectual perception and analysis of that process. It is in this context that the role of women is discussed in the novels of Manju Kapur (Jagatheeswari, 2017: 100).

\section{Discussion and Conclusion}

In this novel, Home, Manju Kapur makes exemplary attempt to give new directions to dynamics of relationships that exist between men and women in a home. For example, Manju Kapur projects men as very supportive of their wives and in doing so, she breaks away with traditional projection of antagonistic relationship of husband-wife that has been so far dealt with at length in Indian English Literature. Such healthy relationship between husband \& wife in a home, that Kapur provokes through her novel, for example, relationship of Sona-Yashpal, Rupa-Premnath, would surely contribute in the development of healthy home, a home full of happiness, bliss and aesthetic pleasure and such environment of a home is referred to as poetics of home. On the other, Home encompasses activities, actions, and policies that are used in a family to gain and hold power over others and such rendering of activities in a home is termed as politics of home. The three homes discussed, that is, the Banwari Lal's home, Rupa's home and Nisha's home reveal the interplay of politics and poetics in home. It is evident from the discussion that the power balances and social relations within domestic spaces influence women's notions of their identity and social status. Rituparna Bhattacharyya (2015) in her extensive research article based on sexual assault against women in India had referred to the book The Production of Space by Henri Lefebvre in which the writer testifies 'the manner in which a particular space is created, coded and used through the processes of social, political and everyday practices'(Bhattacharyya, 2015: 1343). Bhattacharyya further drew a theoretical analysis of 'representations of space' wherein spaces of representation 'address the ways through which one can reconcile mental space and real space: a space, tangent upon the physical and social spheres of an individual or a group of people, and through which social relations are reproduced' (Bhattacharyya, 2015: 1344). Traditions and conventions go a long way in the shaping of identity of individuals living in a family, in a home. Indian women, very often, are seen as custodian of traditional beliefs and customs. Clara Nubile (2003) in the Danger of Gender observes:

In modern India the situation is still far from an ideal, liberated, democratic model. Indian Women keep on struggling against the burden of tradition, against the legacy of the past and the orthodoxy of patriarchal system (Clara, 2003: 27).

In Indian society, the home remains the primary arena of social life for Indian women. Home defines and prescribes the social roles that women would play, the daughter, the wife or the mother. Home renders certain policies to control the activities of women and such policies, often termed as traditions and conventions are used to gain and hold power over women. Women internalise the social engineering laws so profoundly that they become unable to realise the extent to which they are subjugated in the name of family. The character of Sona is undoubtedly an example of that. Manju Kapur attempts to do away with such social prejudices. Pooja Malik (2017) has also opined on the same line:

Manju Kapur is always aware [of] the current happenings around the society and she gives it expression in her novels also. Nisha is the representative of the changing image of [a] woman in the society who is educated and selfconfident (Malik, 2017: 17).

Nisha, the protagonist of the novel, is shown as determined as Virmati of Difficult Daughters (first novel of Manju Kapur) in the staking of domestic territory and the changing of identity. Though Nisha tries her best and becomes successful to a great extent in the staking of domestic territory (in her parental house) and the changing of identity (becoming a businesswoman) but the end of the novel reveals that just because she fails to alter her relegated domestic roles in her new home, she fails to effect changes in her identity in her new 
home. Through Nisha, Manju Kapur portrays that image of an Indian woman who is a blend of tradition and modernity. Manju Kapur is always aware of the current happenings around the society, and she gives it expression in her novels also. Nisha is the representative of the changing image of woman in the society who is educated and self-confident.

\section{References}

Beauvoir, S. d. (1983). The Second Sex. (H. Translated and Edited by H.M.Parshley, Trans.) Harmondsworth: Penguin.

Bhasin, K. (1993). What is Patriarchy? New Delhi: Kali For Women.

Bhattacharyya, R. and Singh, S. (2018). Exclusion (and Seclusion): Geographies of Disowned Widows of India, GeoJournal, 83 (4), 757-774, DOI: 10.1007/s10708-017-9800-0

Bhattacharyya, R. (2019). Symbolic Violence and Misrecognition: Scripting Gender among Middle class Women, India. Society and Culture in South Asia , 5 (1), 19-46, https://doi.org/10.1177/2393861718787870 .

Bhattacharyya, R. (2017). Sociologies of India's Missing Children. Asian Social Work and Policy Review (11), 90-101, https://doi.org/10.1111/aswp.12116

Bhattachayya, R. (2015). Understanding the Spatialities of Sexual Assault Against Indian Women in India. Gender, Place and Culture, 22 (9), 1340-1356, https://doi.org/10.1080/0966369X.2014.96968 4

Bhattacharyya, R. (2009). Examining the Changing Status and Role of Middle-class Assamese Women: Lessons from the Lives of University Students, PhD thesis. Newcastle University, UK.

Bradley, H. (1999). Gender and Power in the Workplace: Analysing the Impact of Economic Change. Basingstoke: Macmillan.

Burton, A. (1998). Imperialism at Home: Race and Victorian Women's Fiction by Susan Meyer; The Politics of Home: Postcolonial Relocations and Twentieth-Century Fiction by Rosemary
Marangoly George. Social History, 23 (1), 122126.

Chakrabarty, D. (2002). Habitations of Modernity - Essays in the Wake of Subaltern Studies. Chicago: The University of Chicago.

Chaudhuri, M. (2012). Indian "Modernity" and "Tradition": A Gender Perspective. Sociological Review, 2 (178), 277-289.

Das, T.K, Bhattacharyya, R. Alam, F.Md., and Parvin, A. (2016). Domestic Violence in Sylhet, Bangladesh: Analysing the Experiences of Abused Women. Social Change, 46(1), 106-123, https://doi.org/10.1177/0049085715618561

Das, T.K, Alam, F.Md., Bhattacharyya, R. and Parvin, A. (2015). Causes and Contexts of Domestic Violence:Tales of Help-Seeking Married Women in Sylhet,Bangladesh. Asian Social Work and Policy Review, 9(2), 114, https://doi.org/10.1111/aswp.12055 Hobsbawm, E. (1983). Introduction: Inventing Traditions. In E. H. Ranger (Ed.), The Invention of Tradition (pp. 1 - 14). Cambridge: Cambridge UP.

Jagatheeswari, R. (2017). The Image of New Woman in Manju Kapur's A Married Woman and Home. Language in India, 17 (3), 90 - 102.

Kahlon, M. (2011). Family Structure in Manju Kapur's Difficult Daughters and Home. The Indian Review of World Literature in English, 7 (2), 1-11.

Kapur, M. (1998). Difficult Daughters. London: Faber and Faber Limited.

Kapur, M. (2006). Home. London: Faber and Faber.

Kaur, P. (2016). Emancipation and Rehabilitation in Manju Kapur's Home: A Study of Family Values. International Journal on Studies in English Language and Literature (IJSELL), 4(11), 19-21.

Lau, L. (2006). Emotional and Domestic Territories: The Positionality of Women as Reflected in the Landscape of the Home in Contemporary South Asian Women's Writings. Modern Asian Studies, 40(4), 1097-1116. 
Malik, P. (2017). Home- A Reality or an Illusion. International Journal of Recent Research Aspects, 4(2), 16-17.

Mee, J. (1998). The Politics of Home:

Postcolonial Relocations and TwentiethCenturyFiction by Rosemary Marangoly George. The Review of English Studies, 49(196), 542-543.

Nubile, C. (2003). The Danger of Gender: Caste, Class and Gender in Contemporary Indian Women's Writing. New Delhi: Sarup \& Sons.

Phukan, B. R. (2015). Negotiating the Notion of Identity and Space in Manju Kapur's.

International Journal of English Language, Literature and Humanities, 2(10), 60-67.

Vauquline, P. (2015). Socialisation Process, Power Relations and Domestic Violence: Marginal Voices of Assamese Women. Space and Culture, India, 3(2), 54-71.

https://doi.org/10.20896/saci.v3i2.155

Wiemann, D. (2008). Genres of Modernity: Contemporary Indian Novels in English. Brill.

Yuval - Davis, N. (1992). Fundamentalism, Multiculturalism and Women in Britain. In J. D.
Rattansi (Ed.), Race, Culture \& Difference (pp. 278-292). New Delhi: Sage

\section{About the Authors}

Ms Adwitiya Gope is presently working as an Assistant Professor of English at Tripura Institute of Technology, Narsingarh, West Tripura. She has a teaching experience of 15 (fifteen) years. Her areas of academic interests are - cultural studies, Indian writing in English, New literature in English, Business Communication. She has published three research articles in reputed journals and three book chapters.

Dr. Gyanabati Khuraijam is working as Assistant Professor (English) in the Department of Management, Humanities \& Social Sciences at National Institute of Technology, Agartala. She obtained her Ph.D from Manipur University. Her areas of interests are Commonwealth Literature, Indian Writing in English, Gender Studies, Postcolonial Studies, Communication, etc. Her research articles have been published in many international journals of repute. She has also authored two books. 